\title{
Evaluation of AMHTS
}

\author{
鈴 木 豊 明*
}

我が国では1954年に人間ドック，1960年 2 日ドック， 1970年東芝で AMHTS が開設され, 現在全国主要病院 の15.2\%，320病院と 48 の AMHTS 施設が総合健診活 動を行っている。受診者の数も年々増え, JHA調 査で は, 昨年度 25 万人の総合健診受診者中 $32.6 \%$ AMHTS が占め, 健診の主役となり, 検査時間の短縮, 多数処 理, 精確性等の特性を生かし, 向後更に増加, 国民の医 療に果す役割は益々増大すると思う。私は, 長く人間ド ックにたずさわってきた立場から, AMHTS の評価に つい述べる。

AMHTS の検查項目では聴力検査が入り, 胆囊検查 が除かれている如く, その性質上, 自動化され難い所見 項目は敬遠されがちであるが, 向後, 健診に必要な項目 をどのよらに組入れるかが問題になる。

検查項目が健診に適正であるかどらか, 異常発見頻 度, 精検率, 健診後の事後発生（特に死亡例）の検討, 健診データーの False positiv, false negativ, 健診者 並社会的評価から批判を加え, 死亡例の受診時の Rish factor の発見率, 疾病構造の変化, Follow up study 受診時の 追加検查等の検討から, AMHTS は成人病健 診には至適であるが，若年者には別のスケジュール，40 歳で Data Base のための現行検査, 更に反復者, 高年 者には別途の配慮が必要とされる。

精度管理の大切なことはいらまでもない。

成績判定にあたっては，標準価の設定，特に個人の正 常值, presymptomatology の確立が大切である。又 AMHTS では Data の Collecting, manipulation, storing ともに優れ, 従来の人間ドックの遠く及ぶとこ ろでない。標準化, Data-bank の設立がのぞまれ， た AMHTSの Data 集積が，個人の健康管理に利用 されるだけでなく, 向後正常値の設定や, 新しい診断 学, 疫学等医学に果す役割は計りしれない。

AMHTS では, システムの性質上, 生活指導, 精検, Follow up 等の 健診後の事後処理がプログラムされ,
らまく行われることが大切である。AMHTS 認定資料, 人間ドックの実施医院のアンケート調查によると, AMHTS 受診者 1 人あたりの面接所要時間は全国平均 14.5 分で人間ドックに比べて短く, 受持医と受診者との 間にさらに十分な対話, 問診, 診察生活指導等の時間が 望まれる。

また, AMHTS が Screening 検查であるかぎり, 精密検査が必要である。要精検指示率は, 平均 $45.4 \%$ ドックの $36.4 \%$ よ多いが, ドックでは受診病院で引つ づき連続的に精検, Follow up が行われ易いが, AMHTS では精検の指示をらけながら，実際に精検をうけ るものは精検部門併設施設でも40\%にすぎず，大部分が 精検部門を持たず，ホームドクター制の確立されていな い我が国の現状では大きな弱点となっている。1 施設 1 日当りの受診者数は AMHTS 34, 2 日ドック 2.8 で, Counseling Doctor 当りの受診者は $9: 2$ である。

Skin ship の問題は, 䀣念される程のことはなく, ア ンケート調查でも利用者の AMHTS に対する信頼は高 まっている。ただ健診データーが，その後の健康管理， 疾病予防にどの程度利用されているか, 甚だ疑問で, 受 診者教育に努める必要がある。

要するに, AMHTS は, 機能の特性を知れば多量処 理, 精確信頼をもった, General health check up と して有力のものと考えられる。ただし, 健診に必要で, 自動化し難い検查項目を向後どう処理するか, また Counseling, 精検, Follow up 等に対する十分な考虑 が必要である。

また, 成人病健診のみでなく, 消化器, 循環器等, 特 定疾患の精查を目的とした健康診断, 地域, 職域の健 診, 健康管理にむすびついたシステムが, 向後大きな課 題となり，これらに対して AMHTS が大きな貢献をす るものと確信する。

\section{* 東京警察病院}

